REVISTA DE DERECHO UNED, núm. 5, 2009

\title{
LA ACCIÓN ADMINISTRATIVA SOBRE EL HECHO CINEMATOGRÁFICO DURANTE EL FRANQUISMO
}

\author{
RAÚl C. CANCIO FERNÁNDEZ ${ }^{1}$
}

Resumen: La historia del Cine español durante la dictadura de Franco fue, de hecho, la historia de la evolución de las diferentes sensibilidades políticas que se sucedieron en el poder desde 1939 hasta 1975. El grado de regulación que experimentó la industria cinematográfica española por parte de la Administración, desde todos los puntos de vista que permite la acción administrativa, lo despojó de toda referencia a lo puramente estético, creativo o generacional, configurando la Gaceta Oficial como el auténtico muñidor de la evolución de nuestro cine, un acontecimiento sin parangón en los países de nuestro entorno.

Palabras clave: Dictadura, Cine español, Censura, Criterios estéticos.

Abstract: The history of Spanish cinema during the Franco dictatorship was, in fact, the story of the evolution of the different political sensitivities that were followed in power from 1939 to 1975 . The degree of regulation that the Spanish film industry suffered by the administration, from all points of view which allows the administrative action, stripped of any reference to that purely aesthetic, creative or generational, configuring the Official Gazette as the true configurator of the evolution of our cinema, an event without parallel in the surrounding countries.

Key words: Dictatorship. Spanish cinema. Censorship. Aesthetic criteria.

Sumario: I. Autarquía política y cinematográfica (193-1950).I.1. Censura en la Guerra Civil.-I.2. El Nuevo Estado Cinemato-

\footnotetext{
1 Doctor en derecho. Letrado del Tribunal Supremo (Sala de lo Contencioso-administrativo).
} 
gráfico. a) Las medidas de control. b) Las medidas de protección. c) Creadores a la sombra del BOE.-II. La década ominosa de Arias Salgado: continuismo y disidencia (1951-1961).-II.1. García Escudero y el escándalo de Surcos.-II.2. Presión económica como instrumento censor: Mendoza de la Cerda acaba con Argamasilla de la Cerda.-II.3. Las Conversaciones de Salamanca.-II.4. Viridiana y el final de una etapa.-III. Fraga, aperturismo formal, intransigencia material (1962-1969).-III.1. Nuevo y sin embargo previsible escenario censor.-III.2. El dirigismo de García Escudero: proteccionismo industrial y patrocinio del Nuevo Cine Español.-III.3. Decepción y recrudecimiento intervencionista.-III.4. Tristana.-IV. Se cierra el círculo: de la oscuridad de Sánchez Bella al frustrado nuevo aperturismo de Pío Cabanillas (19701975).-IV.1. Crisis económica e integrismo moral.-IV.2. Renovadas ilusiones, reiteradas frustraciones.

En memoria de mi abuelo Raúl Cancio, actor, guionista y director de cine.

En todos los países de nuestro entorno puede advertirse una evolución de sus cinematografías desarrollada esencialmente en el marco de criterios bien de naturaleza creativa, bien de índole socio-cultural o merced a la aparición de creadores que supusieron un cambio, una innovación o una ruptura en el panorama creativo existente, todo ello en un escenario político común, el de sistemas democráticos recién salidos del negro túnel de la II Guerra Mundial.

Naturalmente, en el cine español también puede seguirse una evolución y un desarrollo desde los primeros años cuarenta hasta la mitad de la década de los setenta, pero a diferencia de los países a los que antes nos hemos referido, la transformación de nuestro cine durante esos casi cuarenta años no atendió a pautas estéticas, culturales o puramente intelectivas, sino que cada uno de los hitos en los que dicha evolución puede estructurarse respondieron casi y exclusivamente a factores de naturaleza legislativa o gubernamental, como reflejo de la absorbente influencia que la acción administrativa ejerció sobre el hecho cinematográfico español.

Siguiendo este guión, se abordará a continuación la manera en que el aparato estatal, a través de disposiciones de todo rango normativo fue el verdadero muñidor del desarrollo del cine español durante la dictadura franquista, estructurando su estudio en cuatro grandes etapas, según el ya clásico entendimiento de Ro- 
mán Gubern²: autarquía política y cinematográfica (1939-1950); la década ominosa de Arias Salgado: continuismo y disidencia (19511961); Fraga, apertura y deterioro final (1962-1969) y, por último, rearme del rigor censor de la mano de Sánchez Bella y fin del espejismo aperturista de Pio Cabanillas (1970-1975).

\section{AUTARQUIA POLITICA Y CINEMATOGRAFICA (1939-1950)}

\section{I.1. Censura en la guerra civil}

Si bien esta primera etapa se iniciaría con la victoria de los sublevados, no resultaría comprensible el análisis de este primer periodo sin retrotraernos a los años de la contienda, pues fue allí cuando por parte de la facción rebelde se configuraron las estructuras primigenias del aparato censor más tarde institucionalizado una vez ganada la guerra. Apenas un mes después de la sublevación militar, concretamente el 24 de agosto de 1936, la Junta de Defensa Nacional dictaba una Orden por la que se transformaba el Gabinete de Prensa creado por Orden de 5 de agosto, en la Oficina de Prensa y Propaganda, atribuyéndola las competencias exclusivas sobre los servicios relacionados con la información y la propaganda transmitida cualquiera que fuese el soporte de las mismas. Esta arcaica disposición fue perfeccionada poco después en lo que sería el primer organismo estable de supervisión y fiscalización, la Delegación para Prensa y Propaganda, constituida merced a un Decreto de 11 de enero de 1937.

La creciente burocratización del Nuevo Estado franquista generó una proliferación de unidades censoras descoordinadas y dispersas, cuya reorganización se produjo en virtud de la Orden Circular de 19 de octubre de 1937, por la que se atribuía a la Delegación del Estado para la Prensa y Propaganda la suprema dirección de la censura cinematográfica, adscribiéndose a ella a todos los organismos con competencias en la materia. Un grado superior de sofisticación en la maquinaria censora vino de la mano del recién creado Ministerio de Gobernación (al fusionarse Interior y Orden Público tras la muerte del titular de este último, Martínez Anido), desde donde el por entonces todopoderoso Serrano Súñer, asumió las competencias sobre Prensa y Propaganda nombrando por Decreto de 2 de marzo

${ }^{2}$ GUBERN, R., MONTERDE, J.E., PEREZ PERUCHA, J. y TORREIRO, C.: «Historia del cine español», Cátedra, Madrid, 2004. 
de 1938 a Dionisio Ridruejo nuevo Jefe del Servicio Nacional de Propaganda, quien a su vez por Orden de 2 de noviembre de 1938 estableció un sistema de censura de doble instancia a través de la Junta Superior ${ }^{3}$, y de la Comisión de Censura ${ }^{4}$ Cinematográfica, asumiendo las tareas de vigilancia e inspección los gobernadores civiles en las capitales de provincia ${ }^{5}$ y los alcaldes en las demás poblaciones.

\section{I.2. El Nuevo Estado Cinematográfico}

La reconstitución del aparato cinematográfico por parte de las autoridades franquistas se cimentó sobre dos tipos de mecanismos básicos: de control y de protección. A su vez, los primeros se estructuraban en tres categorías nucleares: la censura tradicional, el control de la información a través del cine mediante la creación del Noticiero Documental (NO-DO) y la censura idiomática, cuya derivada en forma de concesión de licencias de doblaje, junto con la clasificación de la producción española, constituían las herramientas básicas de protección.

\section{a) Las medidas de control}

La primera disposición, una vez terminada la guerra, dictada por las autoridades franquistas fue precisamente de naturaleza controladora y se sustanció en la Orden del Ministerio de Gobernación de 15 de julio de 1939, por la que se creaba una Sección de Censura dependiente de la Jefatura del Servicio Nacional de Propaganda y afecta a la Secretaría general, que sometía a la fiscalización de este nuevo organismo y con carácter previo los guiones y argumentos, que una vez evaluados podían recibir alguna de las siguientes calificaciones: aprobado, suspendido temporalmente o rechazado.

3 Su primer presidente fue el escritor Melchor Fernández Almagro, y el resto de integrantes: García Viñolas, los padres Alonso y Peyró, Muquiz, del Ejército y Valenzuela de Educación.

${ }^{4}$ La Comisión quedó constituida originariamente por Manuel A. García Viñolas (Jefe del Departamento Nacional de Cinematografía); el padre Puyal (autoridad eclesiástica); Romualdo Álvarez de Toledo (Educación) y el Coronel Giménez Ortega.

${ }^{5}$ La excepción a esta regla se verificó en Barcelona, que sufrió un régimen de ocupación especial, asumiendo el general Eliseo Álvarez Arenas, Subsecretario de Orden Público, el mando de la plaza ocupada, que incluía la requisa y control de todo el material gráfico existente en la ciudad. 
Una vez declarado apto el guión, la famélica ${ }^{6}$ industria cinematográfica española de posguerra que se aventuraba a producir un largometraje debía someterse a las normas para la filmación dentro del territorio nacional recogidas en la Orden de 9 de abril de 1940, que imponía a las productoras la obligación de presentar un programa completo de producción para los primeros seis meses del año en curso que, una vez aprobados conjuntamente, cada película, de manera individualizada, debía obtener el preceptivo permiso de rodaje emitido por el nuevo Departamento de Cinematografía creado por Orden de 21 de febrero de 1940.

Como se avanzaba más arriba, un hito relevante en el devenir de la industria cinematográfica española, en consonancia siempre con el contexto político y las sensibilidades ideológicas dominantes en la amalgama del poder franquista, fue la transferencia de los Servicios de Prensa y Propaganda a la Vicesecretaría de Educación de F.E.T. y de las J.O.N.S., creada en virtud de la Ley de 20 de mayo de 1941, y que otorgaba por tanto a la Falange las competencias en materia censora, cuya praxis fue reorganizada por la Orden de 23 de noviembre de 1942, de la mano, primero, del vicesecretario Gabriel Arias-Salgado, que ya anunciaba maneras y, un año después, del camarada Jato Miranda, ya como Delegado Nacional de Propaganda de la Falange. El cenit de la influencia del Movimiento sobre el cine español se alcanzó en 1942 con la asunción por parte de del Sindicato Nacional del Espectáculo de las competencias que tenía la Subcomisión Reguladora de Cinematografía. Como veremos más adelante, esta preeminencia de los sectores falangistas durante los primeros años de la posguerra, tendrá su reflejo en la temática de las producciones que se por entonces se hicieron.

Sin embargo, este poder fue efímero. Por Decreto-Ley de 27 de julio de 1945, se transfiere todos los servicios y organismos que en materia de prensa y propaganda y sus respectivas competencias de la Secretaría General de Falange a la nueva Subsecretaría de Educación Popular, adscrita al Ministerio de Educación Nacional. Nótese a este

${ }^{6}$ Puede decirse literalmente famélica. Tras rodar un escena del film Los cuatro Robinsones (1939, García Maroto) en la que los protagonistas veían un espejismo compuesto por apetitosas viandas como un faisán, un jamón y una langosta, comprobaron al positivizarla que la misma era defectuosa y decidieron realizar una nueva toma al día siguiente. La toma no pudio efectuarse pues el administrador de la producción se dio un homenaje esa misma noche con el suculento atrezzo, no pudiendo encontrar sustitutos para esos exquisitos bocados (El cine español contado con sencillez, MARTINEZ RODRIGUEZ, A.C., CASTRO-VILLACAÑAS, E. y ZAVALA, J., Maeva, Madrid, 2007). 
respecto como los acontecimientos internacionales - la derrota del Eje esencialmente- hacen virar radicalmente los posicionamientos políticos de Franco, incorporándose al gabinete franquista en Exteriores el miembro de Acción Católica Martín Artajo, y quedando únicamente dos ministros de extracción falangista, Girón de Velasco en Trabajo y Fernández Cuesta como Secretario General del Movimiento. Su derivada en materia cinematográfica más inmediata fue la postergación de la influencia del Movimiento a favor de posturas tradicionalistas y católicas, que se manifiestan en este trasvase competencial que, además, desliza un velado reproche de provisionalidad a la etapa falangista al frente del aparato cinematográfico.

En este nuevo escenario dominado por el nacional-catolicismo -representado por el nuevo ministro del ramo, el integrista Ibáñez Martín- y cada vez más alejado de planteamientos netamente fascistas o filonacionalsocialistas, la influencia de la moral católica en el plano cinematográfico tuvo su primer y más importante exponente en la creación de la Junta Superior de Orientación Cinematográfica mediante Orden de 28 de junio de 1946, y que vino a refundir la Junta Superior y la Comisión Nacional de Censura Cinematográfica, constituyéndose como organismo superior consultivo y asesor de la dirección general de Cinematografía y Teatro - cuyo titular era por entonces Gabriel García Espina- sobre aquellas cuestiones referentes a censura y control de contenidos. El régimen interior de la Junta fue regulado de manera prolija posteriormente por Orden de 7 de octubre de 1947.

Como muestra de dicha influencia, el art. $5^{\circ}$ de la citada Orden, reservaba un derecho de veto al vocal eclesiástico en caso de desacuerdo expreso con la mayoría de la Junta ${ }^{7}$, en la que, por cierto, no se preveía representación del estamento militar.

Ello también nos da una idea de las tendencias represivas de la censura cinematográfica, mucho más pendientes del cuidado de la moral sexual de los españoles que de aspectos políticos o ideológicos, habida cuenta de la casi inexistente actividad política tras la guerra civil, que hacia inviable un frente de oposición interno dado el mo-

${ }^{7}$ La primera composición de esta Junta fue: presidente, Gabriel García Espina, vicepresidente, Guillermo Salvador de Reyna Medina, vocales: Gustavo Navarro y Alonso de Tejada (Aduanas); David Jato Miranda (SNE); Fernando de Galainena Hererro de Tejada (subcomisión Reguladora de la Cinematografía), Manuel Machado Ruiz, Pío García Escudero, Manuel Torres López, Luis Fernando Domínguez de Igoa, Francisco Ortiz Muñoz y Joaquín Soriano Roesset, siendo designado como vocal eclesiástico fray Mauricio de Begoña y suplente, fray Constancio de Aldeaseca. 
nolitismo ideológico imperante lo cual, y dejando a un lado el perverso y lejano ogro comunista de Moscú, hizo que la acción censora priorizase sus esfuerzos en la persecución de cuestiones vinculadas a la moralidad sexual, en donde, consecuentemente, el papel de la Iglesia fue decisivo.

La orfandad casi absoluta de cualquier tipo de disidencia interna impidió que la censura tuviera que intervenir prácticamente en ningún largometraje español, pues la robustez del régimen autoritario franquista disuadía a productores y cineastas de cualquier intento de realizar películas que cuestionaran políticamente la situación nacional. Adviértase que únicamente dos largometrajes - y ya superada la criba previa por parte de la Comisión, lo cual relativiza su verdadero peso- fueron fulminantemente retirados de la circulación. El primero, El crucero Baleares (1941, del Campo) que tras su pase ante la jerarquía del Ministerio de la Marina se decretó su prohibición inmediata, quizá por entender que el tratamiento del episodio bélico no estaba a la altura que el acontecimiento exigía o bien porque reflejaba con demasiada veracidad lo que aconteció en marzo de 1938.

La otra película retirada fue Rojo y Negro (1942, Arévalo), que describía los amores entre una joven falangista (Conchita Montenegro) y un comunista (Ismael Merlo), finalmente asesinados por las milicias populares en el Madrid de 1936 y que tras su estreno en el cine Capitol el 25 de mayo de 1942 fue suprimida de la cartelera. Estos dos episodios supusieron una inequívoca advertencia a la industria cinematográfica acerca del tratamiento de temas políticos que no fue obviada, instaurándose desde entonces un tratamiento apologético, maniqueo y triunfalista de estas cuestiones al tiempo que sugería una abanico de géneros muy determinado. Repárese en que desde 1945, fecha del desembarco de los ultracatolicistas, hasta 1950, únicamente se produjeron dos largometrajes sobre la guerra civil, El santuario no se rinde (1949, Ruiz Castillo) y Servicio en el mar (1950, Suárez de Lezo).

Como se avanzó anteriormente, la preeminencia de sectores falangistas en el puente de mando de la supervisión cultural durante estos primeros años del franquismo tuvo lógicamente su reflejo en los géneros que configuraron este paleofranquismo cinematográfico. Así, la pública admiración de Primo de Rivera por la obra de Kipling y la heroica muerte de Gary Cooper en The lives of a bengal lancer (1935, Hathaway) marcaron en producciones de corte colonial como Harka (1941, Arévalo), Legión de Héroes (1941, Fortuny) o iA mi la legión! (1942, Orduña). La propaganda del ideario falangista en su 
versión bélica tuvo asimismo cabida en largometrajes como Escuadrilla (1941, Román) o el ya citado y defenestrado El Crucero Baleares. La constatada experiencia de las centurias falangistas en el quintacolumnismo también influyó en un subgénero de temáticas de retaguardia, en donde son de destacar Frente de Madrid (1939, Neville), Por qué te vi llorar (1941, Orduña) o la también reseñada Rojo y Negro. Finalmente, el anhelo falangista de recuperar las esencias patrias en los orígenes de la nación española, que les llevó un proceso de idealización del periodo de la reconquista y del legado imperial como ejemplo de supremacía de lo español en el mundo, se manifestó en un género histórico impregnado de un pueril maniqueísmo, en donde se configuró una insólita galería de mujeres ilustres y heroicas, depositarias de la virtud y trasunto de la madre patria (Eugenia de Montijo, 1944, López Rubio), ahondándose en las raíces de la hispanidad a través de la reconquista, que además les sirvió para trazar un paralelismo con los orígenes del franquismo y la Cruzada que supuso su guerra de liberación (El Abanderado, 1943, Adarvín). Por último, y como compendio de todos estos temas y géneros, no podemos dejar de citar Raza (1942, Sáenz de Heredia), en la cual Franco/Juan de Andrade supera simbólicamente lo que consideraba como deficiencias y defectos propios y de su familia a través de las vicisitudes de la familia Churruca, como representantes del ideario nacional-católico instaurado por los vencedores. No obstante, debe advertirse que un análisis comparativo de la producción por géneros durante la década de los cuarenta ofrece algunos datos que contradicen la creencia de que en esos años sólo se hizo cine como vehículo propagandístico. En efecto, entre 1939 y 1950 se rodaron 83 comedias sentimentales, 66 comedias dramáticas y 58 dramas, mientras que fueron únicamente 7 las películas de temática religiosa, 18 bélicas y de espionaje, y 20 históricas.

Para concluir con la cuestión de los instrumentos de control y tomando como modelo el Istituto Luce italiano, la Vicesecretaría de Educación Popular falangista dirigida por Arias Salgado dictó el 17 de diciembre de 1942 una Orden por la que se establecía la obligatoriedad, a partir del 1 de enero de 1943, de proyectar los espacios del Noticiario y Documentales Cinematográficos (NO-DO) en todas la salas, concediendo a la entidad NO-DO la exclusiva competencia en la elaboración, edición y proyección de documentales cinematográficos lo que, al margen de servir como vehículo propagandístico de primer nivel -inauguraciones de pantanos y carreteras-, como instrumento de efectiva desinformación — toros, fútbol, exhibiciones del $1^{\circ} \mathrm{de}$ mayo-, finalmente, como cordón sanitario con respecto a los noti- 
cieros extranjeros - LUCE, UFA o Fox-Movietone- fue además una verdadera traba para el desarrollo de nuevos formatos cinematográficos — cortos, animación, jóvenes realizadores - al resultar obligatoria su exhibición al inicio de cada film, ni más ni menos que hasta el 1 de enero de 1976.

\section{b) Las medidas de protección}

Junto a los mecanismos de control, la pieza maestra del sistema de protección instaurado por las autoridades franquistas fue la concesión de licencias de doblaje a cambio de la producción del cine nacional. Un sistema por cierto radicalmente contradictorio con la política autárquica del régimen, en el que un gran número de las producciones españolas tenían como único fin la obtención de permisos de doblaje, que era realmente la fuente de ingresos más fiable a la vista del éxito de público de los films doblados. Para evitar que películas absolutamente inconsistentes fueran realizadas únicamente como moneda de cambio para la obtención de permisos de doblaje, la Subcomisión Reguladora de la Cinematografía estableció una baremo clasificatorio en el que la concesión de licencias se anudara a la calidad de las películas, estableciéndose al respecto tres categorías. Posteriormente, esta clasificación se completaría con la categoría de «Interés Nacional», reservada a aquellas películas con un cuadro artístico-técnico completamente español y que significasen «la exaltación de valores raciales o de nuestros principios morales y políticos».

Este proteccionismo en materia clasificatoria se robusteció con la presencia de cuotas de pantalla, la creación de gratificaciones y premios para las producciones españolas como fueron los Premios Nacionales de Cinematografía y, por último, y en una fase anterior al producto final, con el sistema de concesión de créditos sindicales.

\section{c) Creadores a la sombra del $B O E$}

Todo lo anterior, que es rigurosamente cierto, no debe ocultar el hecho de que bajo de esa gruesa capa legislativa, en la industria del cine español hubo creadores e intérpretes de notable nivel, cuya única desgracia fue trabajar en unas condiciones políticas que mediatizaron indefectiblemente su talento.

Entre los cineastas, pueden establecerse tres grupos de creadores, atendiendo fundamentalmente a sus orígenes profesionales. Así, y 
en primer lugar, estarían los directores procedentes del cine mudo, cuyas figuras señeras fueron Benito Perojo y Florián Rey, inequívocamente alienados con el régimen de Franco y cuyas carreras discurrieron de forma paralela durante la década de los cuarenta, iniciando con fuerza estos años con Marianela (1940) y Polizón a bordo (1941) respectivamente, para luego ir paulatinamente descendiendo por una pendiente de mediocridad hasta los años cincuenta, en que Perojo abandonó la dirección y Rey culminó esta etapa con plúmbeos dramas históricos cono Cuentos de la Alhambra (1950).

En un segundo grupo se integrarían aquellos directores que iniciaron sus trabajos con la República, entre los que cabe destacar al incombustible Ignacio F. Iquino, que apostó claramente por la comercialidad de sus films en perjuicio de la calidad (Turbante blanco, 1943); Sáenz de Heredia, máximo exponente de la cinematografía oficial —Raza (1942) — y auténtico precursor de géneros en el páramo cinematográfico español de esos años, introduciendo el caligrafismo hispano —El destino se disculpa (1945)_, consolidando el colonialismo imperante con Bambú (1945), incorporando inéditos puntos de vista burgueses en la demagogia imperante -Mariona Rebull (1947)_, y abriendo el ciclo del cine religioso — La mies es mucha (1948)_; Luis Marquina, de irregular trayectoria, capaz tanto de esquivar los tópicos andalucistas en Malvaloca (1942) como de caer en subproductos como Santander, ciudad en llamas (1944); finalmente, este segundo grupo lo cerraría quizá el más talentoso de los directores de esta década, Edgar Neville, capaz tanto de interpretar con éxito el expresionismo de Solana en Domingo de Carnaval (1945) como de firmar una de las mejores comedias de siempre ese mismo año con La vida en un hilo, a la vez de dar muestra de una gran sensibilidad con la versión cinematográfica de la vanguardista obra de Laforet, Nada (1948).

Este repaso de los directores del periodo autárquico se completaría con aquellos que iniciaron su labor profesional precisamente en la posguerra. Y sin duda fue Juan de Orduña el miembro más aventajado. Actor de cine mudo y por tanto, con experiencia en el sector, inició la década, muy en la línea doctrinal falangista, llevando a la pantalla el texto bélico-colonial escrito por Raúl Cancio A mí la legión! (1941), continuando con adaptaciones teatrales de prestigio como Rosas de Otoño (1943), y siguiendo con deliciosas comedias «de teléfonos blancos» en la mejor línea de Lubitsch como Ella, él y sus millones (1944) o Yo no me caso (1944). Ahora bien, y a pesar de su versatilidad, la fama y el éxito absoluto de taquilla lo obtuvo, como ya vimos, con la cultivación del género legendario-historicista y en con- 
creto con Locura de amor (1948), a la que siguieron Agustina de Aragón (1950), La leona de Castilla (1951) o Alba de América (1951).

Exitosas también fueron las primeas comedias de Rafael Gil, antiguo crítico de cine, que de la mano de Cifesa firmó sus mejores trabajos en la primera mitad de la década, con Viaje sin destino (1942), Huella de luz. (1942) y Eloísa está debajo de un almendro (1944).

Distinta suerte sufrieron sin embargo las carreras de otros dos realizadores de este grupo por diferentes motivos. El inequívoco compromiso de Antonio del Amo con la Republica — realizador habitual de documentales para el Ejército Republicano (El paso del Ebro, Alerta, Soldados campesinos, todos de 1938), y encarcelado tras la guerra- le pesó inevitablemente durante estos años a pesar de su sólida formación artística e intelectual, rescatando su experimental Noventa minutos (1949) como ejemplo de ello. La indisimulable disidencia estética con respecto al cine oficial lastró igualmente la carrera de Carlos Serrano de Osma, cuyos planteamientos artísticos excedían con mucho de las alcanforadas estructuras del régimen, dejando, eso sí, insensatas pero interesantes obras como La sirena negra (1947) o la versión de Parsifal (1951).

Por lo que respecta al star-system de la posguerra española, debe ponderarse convenientemente su importancia. La situación económica y política de una sociedad recién salida de una terrible guerra fratricida, a lo que ha de añadirse las graves taras producida en la industria por la acción administrativa en sus múltiples manifestaciones, fomentó que los espectadores buscaran en el cine una válvula de escape de la precaria situación vital que padecían ${ }^{8}$, convirtiéndose los elencos artísticos en el mayor reclamo de las películas.

Así, un film que en su reparto contara con Amparo Rivelles o Alfredo Mayo, garantizaba automáticamente un éxito de taquilla, tanto si actuaban por separado (Harka, Raza, El abanderado; La fe, De mujer a mujer, La leona de de Castilla) como si ambos protagonizaban la película (Malvaloca, Un caballero famoso, Deliciosamente tontos).

Si Alfredo Mayo fue el galán heroico por antonomasia, sintetizando en sus personajes el espíritu triunfalista de posguerra, convirtiéndose incluso en el alter-ego del propio dictador en Raza, el galán que mejor interpretó los perfiles dramáticos y cómicos de ese rol fue Rafael Durán, que valiéndose de su porte distante y elegante y de su

${ }^{8}$ Recuérdese que un porcentaje estadístico abrumador, señalaba a las comedias como el género de mayor producción durante esta década. 
sugerente voz, dio réplica a la principales actrices del momento en títulos como La tonta del bote (1939), con Josita Hernán, Pimentilla (1941), con Marta Santaolalla, La condesa María (1942), con Lina Yegros, Tuvo la culpa Adán (1944) con Luchy Soto y, naturalmente, con la Rivelles en Eloisa está debajo de un almendro (1943).

Para terminar con la terna de galanes, la apostura que asimismo poseía Armando Calvo hizo de este puertorriqueño el Don Juan arquetípico del cine español de posguerra, logrando éxitos notables con El escándalo (1943) y Los últimos de Filipinas (1945).

Estos tres galanes tuvieron, en muchas de sus películas, dos escuderos que bordaron lo que en Hollywood llaman el next boy door - el arquetipo de este perfil en la meca del cine fue sin duda el recientemente fallecido Van Johnson-, es decir, el vecino, al amigo, el camarada, alguien tan cercano que en muchas ocasiones, el público acogía con más cariño que al propio protagonista. Antonio Casal fue el actor con el que muchos españoles de la posguerra se identificaron, por su aspecto afable y bonachón, en películas como El hombre que se quiso matar (1941), Te quiero para mí (1944) o Botón de ancla (1948).

El éxito y la celebridad que adquirió Raúl Cancio en el parnaso artístico de los años cuarenta no fue, como ocurría con Antonio Casal, tanto por su amable y común apariencia - frisaba el donostiarra el 1,80 de la época y su bigote y la sempiterna brillantina le daba un aire aristocrático poco habitual es aquella España de miseria- sino por su desbordaba simpatía y naturalidad ante la cámara. Ello le permitió convertirse tanto en el amigo entrañable y camarada leal de Alfredo Mayo en Harka y Escuadrilla, como en el complemento perfecto de comedias de "teléfonos blanco» como Ella, el y sus millones o Doce lunas de miel (1943), dejando no obstante gotas de su capacidad dramática en papeles mucho más turbios como el Vincent de Fedra. Sus inquietudes artísticas le llevaron además a escribir guiones de temática tan diversa como A mi la legión!, el corto Historia de una botella (1948), Como la tierra (1954), Tres ladrones en casa (1950) y Madrid primavera del mundo (1952), estas dos últimas, dirigidas también por él.

Por último, y para terminar con la nómina de estrellas masculinas de este periodo, pueden destacarse también a Pepe Nieto o Luis Peña, formados ambos en la cantera de Joinville.

Entre las actrices, contaba la leyenda que todos los guiones de los años cuarenta pasaban antes por las manos de Amparito Rivelles, y los que ella rechazaba eran interpretados por las demás. Si fuese 
ello cierto, desde luego que no desaprovecharon la oportunidad inérpretes como Josita Hernán, célebre para siempre por La tonta del bote, Luchy Soto, que se especializó en comedias amables, como Viaje sin destino (1942), Maruchi Fresno, mejor dotada para el drama, (La pródiga, 1946) o Ana Mariscal, que alcanzó fama con Raza, desarrollando después una carrera cinematográfica plena y polivalente, figurando como guionista, directora y productora de sus films (Segundo López, aventurero urbano (1954), algo absolutamente inaudito en la machista sociedad española de la época.

\section{LA DECADA OMINOSA DE ARIAS SALGADO: CONTINUISMO Y DISIDENCIA (1951-1961)}

\section{II.1. García Escudero y el escándalo de Surcos}

Una vez más, será una disposición normativa, en este caso el Decreto de 19 de julio de 1951, la que jalone la segunda gran etapa en la evolución del cine español. En efecto, la situación socio-política de la España de 1950 ha cambiado sensiblemente con respecto a la última década. Desde el punto de vista internacional, se constata una relajación notable en el aislacionismo autárquico de los años cuarenta, iniciándose una tímida etapa de apertura de la mano de los Estados Unidos; en el plano interno, también algo se mueve merced a la creciente actividad de movimientos estudiantiles en el seno de la Universidad y a la definitiva postergación de los principios falangistas en favor de corrientes políticas ultraconservadoras de acento católico. Todo ello desembocó en una profunda remodelación el gabinete del general Franco en el que, por lo que a nosotros nos interesa, fue nombrado por el referido Decreto a Gabriel Arias Salgado como ministro del nuevo departamento de Información y Turismo, en cuyo seno se insertaría la Dirección General de Cinematografía y Teatro, asumiendo todas las competencias que hasta entonces regentaba el Ministerio de Educación Nacional, cuyo nuevo titular, el liberal Ruiz Jiménez, parece que no ofrecía las garantías necesarias para ejercer el necesario control sobre la censura que ofrecía el integrista Arias Salgado.

Para tal menester, su departamento no tardó en reorganizar y unificar el sistema censor que se mantenía incólume desde 1946, creando tres nuevos organismos: el Instituto de Orientación Cinematográfica, la Junta de Clasificación y Censura de Películas Cinematográficas y el Consejo Coordinador de Cinematografía, con la 
clara vocación de armonizar los distintos estamentos con responsabilidades en materia de cinematografía persistentes en la administración.

Esta nueva estructura organizativa estaba integrada en la Dirección General de Cinematografía y Teatro, cuyas vicisitudes en su titularidad fueron un reflejo fidedigno de las tensiones sufridas por el cine español en esta década.

Por decreto de 18 de agosto de 1951, sería nombrado como primer Director General José María García Escudero, personaje de rocambolesca biografía - fue desde ayudante del comisario político de una brigada anarquista durante la guerra civil, hasta instructor de la cusa por el 23-F- y de sólida formación académica, muy interesado en temas relacionados con la cultura y particularmente el cine (y su censura), sobre el que venía escribiendo regularmente en el diario falangista Arriba y que llegó al cargo con una inequívoca voluntad de diseñar una nueva política cinematográfica, si no de ruptura, si al menos que dispensare una cierta seguridad jurídica, unas pautas previsibles para cineastas y productores, especialmente en materia censora.

Debe advertirse, antes de profundizar en las vicisitudes de García Escudero y del éxito o fracaso de su proyecto, que en los años cincuenta, las pautas y criterios censores no eran muy diferentes a los empleados en la etapa de autarquía, huérfanos como se recordará de cualquier sistematicidad y, por tanto, de una arbitrariedad y oportunidad absoluta. No obstante, el progresivo aperturismo y la relajación en el monolitismo de los primeros años cuarenta exigió del aparato censor una mayor actividad que lejos de resultar eficaz, puso de manifiesto las profundas contradicciones y atonías achacables a su falta de rigor y de criterios estables, que tuvieron como efecto más significativo algunos episodios de laxitud difícilmente tolerados en la pasada década.

Este relativismo en la aplicación del tijeretazo censor tuvo no obstante su inmediata réplica con la aparición de la denominada censura extraestatal y cuyo más importante exponente fue la todopoderosa por entonces jerarquía eclesiástica. Habida cuenta que, a juicio de la iglesia católica, la actuación de la Junta de Clasificación resultaba en ocasiones excesivamente laxa en sus valoraciones, el estamento eclesiástico no dudo en organizar una censura propia y vinculante para los católicos, a través de la Oficina Nacional Permanente de Vigilancia de Espectáculos, que generó no pocas fricciones cada vez que, a posteriori de la decisión administrativa, recalificaban una película de manera diferente a la efectuada por la Junta de Clasificación. 
La presión ejercida por esta censura paraestatal y dos títulos en concreto tuvieron mucho que ver con la breve estancia de García Escudero al frente de la Dirección General: Surcos (1951, Nieves Conde) y Alba de América (1951, Orduña). De esta manera se daba además una advertencia a los directores y productores en torno al tratamiento cinematográfico de los temas sociales, cuyo ámbito debía quedar circunscrito al de la caridad cristiana. No es casual que películas como Sor intrépida (1952), La guerra de Dios (1953), El beso de Judas (1954) o El canto del gallo (1955), todas ellas producidas por Aspa Films y dirigidas por Rafael Gil, y de contenido marcadamente religioso, fueran clasificadas de Interés Nacional en ese lustro.

\section{II.2. Presión económica como instrumento censor: Mendoza de la Cerda acaba con Argamasilla de la Cerda}

Con el cese de García Escudero y el nombramiento de Joaquín Argamasilla de la Cerda y Elio, marqués de Santa Clara, por entonces Secretario General de Cinematografía y Teatro y antiguo Jefe del Departamento Nacional de Cinematografía de la Vicesecretaria General de Educación Popular entre 1943 y 1945, se cierra el primer intento serio de aperturismo en el cine español y se abre un periodo en donde el acento censor, — sin descartar la poda tradicional - se pondrá en las medidas proteccionistas de naturaleza económica, habida cuenta de la endeblez del sistema de licencias de doblaje ya estudiadas anteriormente. El nuevo mecanismo, instaurado mediante Orden de 16 de julio de 1952, establecía una clasificación de las películas nacionales atendiendo a su calidad, en las categorías de Interés Nacional, $1 .^{\mathrm{a}} \mathrm{A}, 1 .^{\mathrm{a}} \mathrm{B}$, $2 .^{\mathrm{a}} \mathrm{A}, 2 .^{\mathrm{a}} \mathrm{B}$ y $3 .{ }^{\mathrm{a}}$, categorías a las que se vinculaba la correspondiente subvención, calculada sobre un porcentaje del presupuesto del film. A mayor calificación, mayor porcentaje del presupuesto y mayor importe de la subvención. Lo que pretendía ser un sistema que superase el mercado negro en el que se había convertido el canje de las licencias de doblaje, se convirtió a la postre en una invitación al productor para realizar cintas que agradaren a la Junta, con independencia de su valor artístico, de manera que obtuvieren la mejor calificación posible y por ende, la mayor tajada en forma de subvención, para lo cual, además, se instauraba la práctica fraudulenta de inflar artificiosamente los presupuestos de las películas, de manera que la base sobre la que aplicar el porcentaje correspondiente fuese el más alto posible, generando así una inflación y unos sobrecostes injustificados. El otro elemento central de protección continuó siendo el crédito sindical, aunque en menor medida ante la posibilidad de subvención directa sobre film acabado. 
Finalmente, otro instrumento de intervención estatal fue sin duda el de la promoción de las coproducciones con otros países así como el establecimiento de un marco legal que diera facilidades para la realización de films en suelo español. Lo que no pensaron las autoridades españolas es que esa medida estaba en realidad abriendo una nueva gatera en el edifico censor, al aprovechar esas coproducciones para la instauración del sistema de dobles versiones, mediante el cual, una de ellas era sometida a la censura española, que la cercenaba a gusto, mientras que la otra, sin merma de su contenido, era distribuida al extranjero. En esta praxis fue maestro consumado Iquino - La pecadora (1954), Camino cortado (1955) o Juventud a la intemperie (1961) — contratando a starlettes y estrellas del strip-tease de generosas curvas para las versiones «B», cuyas voluptuosidades eran vedadas al espectador nacional.

Precisamente el escándalo derivado del sistema de dobles versiones en que se vio envuelta la coproducción anglo española That Lady (1955, Young), libre traducción de La princesa de Éboli, tuvo como consecuencia la destitución de Argamasilla de la $\mathrm{Cerda}^{9}$, ante la evidencia de que fuera de España estaba circulando una versión que no dejaba en buen lugar el nombre de Felipe II, seducido ante los encantos de Olivia de Havilland.

Lo cierto es que por Decreto de 25 de febrero de 1955, Manuel Torres López, ex vocal de la Junta de Censura, es nombrado nuevo Director General de Cinematografía, bajo cuyo patrocinio se celebraron pocos meses después de su nombramiento, unas jornadas en la ciudad de Salamanca que marcaron de alguna manera el devenir de la historia del cine en nuestro país.

\section{II.3. Las Conversaciones de Salamanca}

Sin perder un ápice de influencia sobre el cine el aparato burocrático y legislativo, es cierto que en la segunda mitad de la década de los cincuenta, el cine español puede asirse en su desarrollo, no sólo a disposiciones normativas, sino que también pueden detectarse mojones de otra naturaleza. Sin duda, las I Conversaciones Nacionales de Cinematografía organizadas al alimón por la revista Objetivo y por el Cineclub del SEU de Salamanca que dirigía Basilio Martín Patino y patrocinadas por la Dirección General de Cinematografía y Teatro, fueron un claro ejemplo de ello.

9 Que ironía que una película sobre una pariente lejana de director general, Ana Mendoza de la Cerda, fuese la causante de su cese! 
En nuestro particular -y limitado- Manifiesto de Oberhausen, Muñoz Suay abría la discusión con el célebre: «el cine español esta muerto. Viva el cine español».

Las reivindicaciones fundamentales que se plantearon entre los días 14 a 19 de mayo de 1955, giraron en torno a la necesidad de establecer un código de censura que evitara la actuación arbitraria de los órganos censores; la potenciación de la formación cinematográfica; la búsqueda de la excelencia en la producción de películas, evitando que los mecanismos proteccionistas fomentaran la manufactura de films con el único objetivo de obtener subvenciones a cambio y, por último, el fomento racional del cine por parte de la Administración. El evidente posibilismo gradualista de muchas de estas reivindicaciones no impidió sin embargo que, el mero hecho de que por vez primera, se plantearan y discutieran públicamente en un marco patrocinado por la propia Administración, cuestiones hasta entonces consideradas como tabúes, como la censura o la actitud de los poder públicos con respecto al hecho cinematográfico, causará un notable impacto en las estructuras del régimen, en cuyo seno, y como ya tuvimos ocasión de analizar al principio de este capítulo, desde 1951 ya se fraguaban ciertas corrientes de disidencia cinematográfica -Surcos, Esa pareja feliz, Bienvenido Mister Marshall, Cómicos-, cuya consolidación se verificó a raíz de estas simbólicas jornadas.

En efecto, de la mano de dos alumnos de la primera promoción salida de la Escuela Oficial de Cinematografía (EOC), Luis García Berlanga y Juan Antonio Bardem, el cine español da un indudable salto de calidad a la vez que introduce temas, argumentos y contextos claramente innovadores en el panorama cinematográfico. Berlanga, a través primero de amables sainetes no exentos de notables cargas de profundidad (Bienvenido Mister Marshall (1952), Novio a la vista (1953) y después, con cada vez más ácidas sátiras -Los jueves milagro (1957), Plácido (1961) y El verdugo (1963)—, y Bardem, con Muerte de un ciclista (1955), estrenada precisamente durante las Conversaciones Salamanca, Calle Mayor (1956), La venganza (1957) y A las cinco de la tarde (1960), ilustran magistralmente, uno a través del humor y la sátira y, el otro, mediante el retrato costumbrista con ribetes neorrealistas, la sociedad española, trufada de mezquindades y complejos, el provincianismo exacerbado y la psicología hispana de posguerra. Bardem también fue objetivo predilecto de la censura, al punto de obligarle a estrenar Calle Mayor en Venecia, precedida de un rótulo asegurando que cuanto ocurre en la película podía suceder en cual- 
quier país ${ }^{10}$. Asimismo, en La venganza, cuyo título original era Los segadores, la censura obligó a retratar la explotación social a 1930, de manera que fuese el liberalismo el causante de la ruina campesina.

Sin embargo, no debe pasar desapercibido que si bien estos dos grandes autores, y junto a ellos, el también disidente Fernando Fernán Gómez, sufrieron la arbitraria acción de la censura, sus films puede decirse que se mantuvieron en todo momento en el marco del sistema industrial, extremo que no puede decirse de la disidencia periférica representada fundamentalmente por el ya conflictivo Nieves Conde, que se superó con El inquilino (1957), corrosiva crítica de la escasez de vivienda en la España postbélica, que fue literalmente pulverizada por la censura $^{11}$, prohibida directamente por el ministerio de la Vivienda del falangista Arrese $^{12}$ e inédita en muchas capitales de provincia. Algo más de fortuna tuvieron los frescos impregnados de la veta del absurdo inherente a la tradición esperpéntica española que nos dejó la sociedad formada por Marco Ferreri y Rafael Azcona en El pisito (1958), Los Golfos (1959) y El Cochecito (1960), que aunque también fueron pasto de la censura, no sufrieron el acoso recibido por Nieves Conde.

Al margen de la referida consolidación de corrientes cinematográficas disidentes, el "espíritu de Salamanca» se cobró también víctimas en la Administración ${ }^{13}$, sacrificándose nada más y nada menos que al promotor de dichas jornadas, el Director General Torres López, a quien sustituyó por Decreto de 27 de abril de 1956 el vizconde de San Javier, Juan Muñoz Fontán, que dio muestras de cierta flexibilización en la acción censora a través de tres ejemplos concretos: Viaje de Novios (1956), el documental Continente perdido (1956) y la escabrosa producción de Mur Orti, Fedra (1956).

Como ya ocurriese en la anterior década, el empleo de dobles versiones para sortear la censura sobre todo en materia sexual continuó empleándose a finales de los cincuenta, y si entonces fue Iquino el maestro de esta técnica, su puesto lo ocuparía ahora el iconoclasta Jesús

10 Algo parecido ocurrió con la cinta de Florián Rey Audiencia Pública (1946), que fue contextualizada en una ignota república, pues un proceso judicial público en donde afloran los graves problemas de toxicomanía de una mujer no podía suceder en España.

11 En la manipulada escena final, la familia se sube a una camioneta con el rótulo la esperanza en dirección a unos bloques de viviendas nuevos.

12 Refiere Nieves Conde que su camarada le reprochó que en su película, los buenos no llevan corbata y los malos sí.

${ }_{13}$ Y ello a pesar de que el secretario general de Cinematografía, Cano Lechuga, en un artículo en Triunfo el 25 de mayo de 1955, pretendió relativizar los efectos de las Conversaciones calificando la reunión como «especie de chiquillada». 
Franco, quien inició su ciclo sádico —erótico con Gritos en la noche (1961)_, y sus múltiples y más explícitas versiones - Cries in the Night, Horrible Docteur Orlof, L' (Francia); Screams in the Night; The Awful Dr. Orlof (USA); The Demon Doctor (UK) o The Diabolical Dr. Satan-.

\section{II.4. Viridiana y el final de una etapa}

Tras su exilio americano, Luis Buñuel regresa a España en 1960 con un visado de turista en donde, por mediación de Paco Rabal, coincide con el productor mexicano Gustavo Alatriste, esposo de Silvia Pinal a quien Buñuel ya conocía de su etapa mexicana, en el bar del hotel Plaza, convenciéndole el primero para que ruede en España Viridiana. La única condición que exigió el turolense fue que la coproducción española fuese a cargo de UNINCI Films 59, productora fundada en 1949 y presidida en su origen por el que luego fuese director del NO-DO Alberto Reig y que se enmarca en el grupo de productoras que pretendieron, en los años cincuenta, romper con el inmovilismo dominante de la producción española. En este sentido, con una Cifesa en franca decadencia, sustituyéndola en la cumbre la Suevia Films de Cesáreo González, y con la Ifisa de Iquino especializada en productos de serie $B$, surgen una multitud de productoras que, sin salirse de los parámetros, pudiéramos decir oficialistas, si suponen cierta novedad por la especialización de sus productos ${ }^{14}$. Cuando lle-

${ }^{14}$ Así, Aspa Films, y en menor medida Ariel y Pecsa, son sinónimo de películas de temática religiosa; Ágata Films (Dibildos/Lazaga) o Asturias Films pondrán los cimientos del cine desarrollista de los sesenta con cintas de parejas como Las chicas de la cruz roja (1958) y El día de los enamorados (1959) y de comedias sugerentes como la ya citada Viaje de Novios. Junto a ellas, y como decíamos anteriormente, fueron surgiendo pequeñas productoras que abordaron temas atrevidos o bien apostaron por temáticas innovadoras, como fue el caso de Altamira, S.L., (Día tras día, Esa pareja feliz) creada por estudiantes del Instituto de Investigaciones y Experiencias Cinematográficos - Bardem, Berlanga, Bucal—; Manuel Goyanes (Muerte de un ciclista, Calle Mayor, pero también, el ciclo de Marisol); Documento Films (El pisito), Films 59 (Los golfos) o, finalmente, Alfredo Matas y su Jet Films (Plácido). A este grupo de productoras pertenecía UNINCI, que si bien en sus inicios ofrecía un perfil inequívocamente oficialista como demuestra su presidencia a cargo de Reig, durante la década de los cincuenta, y después del éxito absoluto de Bienvenido Mister Marshall, comenzó a sufrir una serie de disensiones internas — con la abrupta salida de Berlanga- que derivaron en un escoramiento a la izquierda de la productora al asumir Bardem el control efectivo de la misma a partir de 1958, fecha que coincide con la paulatina infiltración en la empresa del PCE, no sólo en el plano ideológico, sino como tapadera para sus actividades económicas. No puede por tanto sorprender que Buñuel señalase a UNINCI como la productora de su film, cuyo guión firmó junto con su fiel Julio Alejandro de Castro. 
gó la hora de someter el guión a la censura franquista, ésta objetó el final original de la cinta en el que Viridiana llamaba a la puerta de su primo, él abría y ella entraba cerrándola tras ella. Obediente, Buñuel propuso un final diferente, en el que Jorge, Viridiana y Ramona jugaban una partida de tute, muy del agrado de los elementales censores, que no se dieron cuenta del latente menage a trois que subyacía bajo los naipes. Asimismo, la censura tampoco percibió la crítica sobre la doble moral burguesa, ni la denuncia de la hipócrita caridad cristiana de la novicia, admitiendo incluso la clara provocación visual de la cena de los mendigos, parangonando la última cena de Jesús, siendo su alter ego precisamente el más tullido y desarrapado de aquellos o la no menos mórbida visión de una inexperta Silvia Pinal aprendiendo a ordeñar vacas. Una vez con el plácet de la Junta Censora, el rodaje transcurrió sin sobresaltos, filmándose en los estudios de Bardem y en la Quinta del Pardo, muy cerca de la residencia del general Franco.

La Dirección General de Cinematografía tuvo a bien designar a la película como representante de España en el Festival de Cannes, obteniendo ese año la Palma de Oro y la ovación unánime de público y crítica. El propio Muñoz Fontán fue el encargado de recoger el galardón, considerando que el mismo era un importante aldabonazo para el raquítico cine español del momento. Lo que no podía imaginar el ufano Muñoz Fontán es que, si bien la película había podido burlar a los ineptos censores españoles, a los críticos del L'Observatore Romano no se les podía ir con ese hueso, y al día siguiente se publicó en el diario vaticano una durísima crítica del film, acusándolo de sacrílego y blasfemo, lo que generó una monumental escándalo en Madrid, con la destitución fulminante de Muñoz Fontán y la prohibición absoluta de la cinta, la consigna de no citarla ni en prensa ni radio e incluso la pérdida de nacionalidad española. De las llamas únicamente la salvó su carácter de coproducción. El Sábado de Gloria de 1977, al tiempo que se legalizaba el PCE en España, se estrenaría en Madrid.

\section{FRAGA, APERTURISMO FORMAL, INTRANSIGENCIA MATERIAL (1962-1969)}

De nuevo los condicionantes políticos, manifestados en las distintas sensibilidades del régimen, así como la situación geoestratégica internacional, serán factores determinantes en esta tercera etapa de nuestro viaje. 
La crisis minera asturiana, las crecientes revueltas estudiantiles, la cada vez mayor influencia en el gabinete del Pardo de elementos políticos cercanos al Opus Dei y de marcado perfil técnico o la explosión del turismo como motor de la economía nacional, en el plano interno, y la celebración en la capital bávara del bautizado por el diario Arriba como «Contubernio de Munich» en 1962, cuya repercusión fue exponencialmente aumentada por la histeria de la prensa del Movimiento, en el plano exterior, configuraron el contexto en el cual se fue gestando el inicio de una nueva y, a priori, ilusionante etapa en la historia del cine español.

Esta esperanza en un nuevo clima en el ámbito cinematográfico, estuvo basada fundamentalmente en la destitución del montaraz Arias Salgado al frente de Información y Turismo tras el escándalo muniqués, y su sustitución por el hiperactivo y dinámico Manuel Fraga Iribarne, así como en el nombramiento para el cargo de Director General de Cinematografía del ya citado en esta páginas García Escudero, que en esta segunda etapa anunciaba un mandato de fuertes cambios estructurales en la anquilosada industria cinematográfica.

\section{III.1. Nuevo, y sin embargo previsible escenario censor}

No en vano, García Escudero, como participante en la Conversaciones de Salamanca, se había distinguido como un tenaz crítico del sistema censor establecido, que si bien entendía que debía seguir existiendo, postulaba por el contrario que el mismo debía adecuarse a un código preestablecido que dotara de cierta seguridad jurídica a los diferentes agentes de la industria cinematográfica, así como también, que debía cohonestarse con lo que el llamaba la censura social, concepto indeterminado y de extraordinaria utilidad práctica como luego veremos.

Como prueba de esta nueva cosmovisión de la censura, el primer Decreto promulgado por la nueva dirección general fue el 2373/62, de 20 de septiembre, que reorganizó la Junta de Clasificación y Censura, en la que la triada constituida por el Ejército-la Falange y la Iglesia, fue sustituida por la Política-la Educación y, en eso no se cambió, la Iglesia, lo que venía a ser un mensaje del nuevo talante del Ministerio, de mayor apertura y flexibilidad con el contenido de las películas sometidas a su valoración. En este sentido, fue sin duda significativo y vino a corroborar este nuevo clima de relajación censora, el estreno en 1962 del primer film español en el que aparecía ni más ni menos que un bikini en la pantalla — sobre la fisionomía de una extranjera como Elka Sommer, claro está-, Bahía de Palma (1962, Bosch), muy en la línea de coadyuvar en la promo- 
ción del nuevo becerro de oro español, el turismo, el sol y las bondades de nuestras playas.

Los vientos de cambio auspiciados en Salamanca, tuvieron su primer reflejo en el tan anhelado código de censura, que se instrumentalizó mediante Orden de 9 de febrero de 1963, por la que se aprobaban las Normas de Censura Cinematográfica que, si bien fijaban por fin un contexto jurídico en la praxis censora, ello no las despojaba de una calculada carga de ambigüedad en sus disposiciones que facilitara la labor correctora de la Junta.

\section{III.2. El dirigismo de García Escudero: proteccionismo industrial y patrocinio de Nuevo Cine Español}

Si en materia de censura se habían dado algunos pasos ciertamente ilusionantes, aunque claramente insuficientes, los mayores esfuerzos de García Escudero se proyectaron sobre la creación de unas bases sólidas sobre las que cimentar lo que él definía como «Nuevo Cine Español». Ese pilar se fraguó merced a la Orden de 19 de agosto de 1964, de desarrollo de la Cinematografía Nacional.

El proyecto de García Escudero descansaba sobre dos ejes fundamentales: de una parte, manteniendo y fortaleciendo políticas de corte proteccionista sobre la industria cinematográfica española, como los créditos a plazo medio, las subvenciones del $15 \%$ o los anticipos de un millón de pesetas amortizables en tres anualidades, claramente dirigidas a la industria y el segmento de la producción.

En segundo lugar, a través del patrocinio de directores noveles y nuevos lenguajes, suprimiendo la antigua escala clasificatoria de films, creando por el contrario la categoría de Interés Especial, una versión culta y puesta al día de la pretérita calificación de Interés Nacional. La eclosión de la Nouvell Vague francesa, del Free Cinema de los Angry Young Men británicos o del ya citado Neuer Deutsche Film espoleó al Director General para promocional también es España una corriente de cineastas que, además de dar empleo a los frustrados licenciados de la EOC, sirviera además para producir cintas que por su calidad pudieran representar a España en festivales internacionales y aprovechar su repercusión en aras de lavar la imagen de la dictadura $^{15}$.

15 Esta política de García Escudero, muy mal encajada por los sectores más inmovilistas del régimen, le granjeó el peyorativo sobrenombre de «Director General de Cineclubs». 
De esta manera, y al calor de García Escudero, surgieron entre 1962 y 1967 una serie de directores debutantes - hasta 48 - y un elenco de películas de desigual interés y calidad, pero que tenían en común su vocación de ruptura no sólo con el cine comercial o de régimen, sino también con el de algunos disidentes, como el propio Bardem.

El común denominador de cineastas como Diamante (Los que no fuimos a la guerra, 1965), Patino (Nueve cartas a Berta, 1966), Picazo (La Tía Tula, 1967), Summers (Del rosa al amarillo, 1963), Camus (Soledad, 1967), Mercero (Elegía por un circo, 1970), Camino (España otra vez, 1967), Regueiro (El buen amor, 1963), Erice (Los días perdidos, 1963), Fons (Garabatos, 1963), Olea (Anabel, 1964), Egea (El niño de Vallecas, 1964), Eceiza (El próximo otoño, 1967), Grau (Una historia de amor, 1967), Aranda (Fata/Morgana, 1962), Portabella (No contéis con los dedos, 1967) o Saura (La caza, 1966), fue la de abordar temas viejos desde una nueva perspectiva, con un lenguaje en muchas ocasiones hermético o elíptico y abordando temas de manera oblicua, siempre con el telón de fondo de la complicada relación con los que vivieron la guerra civil, que son ya de una generación pasada, todo ello privilegiando entornos y personajes de provincia, frente a la absorbente centralidad de Madrid, y con innegables rastros autobiográficos en muchas de las obras de estos jóvenes creadores.

Ahora bien, que nadie se lleve a engaño. La promoción desde la administración de estos nuevos cineastas no les eximió de su deber de sometimiento al mecanismo censor, deber por otra parte que les venía impuesto desde el inicio y al que se sometían indefectiblemente al entrar en juego el perverso sistema de subvenciones y ayudas, vinculadas a la aprobación previa de los guiones. Y aun así, argumentos que obtuvieron el visto bueno de la Junta de Clasificación fueron después, ya en celuloide, duramente seccionados por la censura.

Estos episodios censores indudablemente afectaron al pretendido aperturismo de García Escudero, que paulatinamente fue manifestándose más como un slogan formal que como una realidad tangible. Ello se acrecentó de manera exponencial con el episodio protagonizado por la película de Berlanga El verdugo (1963), que tras sufrir un total de catorce cortes, fue finalmente presentada en el Festival de Venecia donde obtuvo el Premio de la Crítica Internacional, lo cual amplificó su significación política de claro rechazo de la pena de muerte bajo la pátina del humor, justo cuando aún coleaban en toda Europa las condenas a muerte ejecutadas en España de Julián Grimau y de los anarquistas Granados Gata y Delgado Martínez. La re- 
acción de Alfredo Sánchez Bella, a la sazón embajador en Roma y futuro titular de Información y Turismo, fue durísima, y queda ilustrada con la carta que el mismo remitió al ministro de Exteriores Castiella, en la que se quejaba amargamente del "gol» que les habían metido con la película de Berlanga, resultándole inconcebible que hubiese podido burlar a los veinticinco miembros de la Junta.

Volviendo al año 1963, García Escudero no fue destituido por el affaire de El verdugo, aunque su destino estuviese marcado por el contexto político sobre el que se deslizaba el régimen. Y ello a pesar de que el director general endureció de nuevo el sistema represivo censor con la promulgación el 14 de enero de 1965 de un Decreto por el que se creaba la nueva Junta de Censura y Apreciación de películas, que no venía sino a añadir más casuística a la ya de por si alambicada estructura censora española, que no cejó en su empeño a pesar de que al año siguiente se suprimiría en los Estado Unidos el nefasto Código Hays.

Entre 1966 y 1967 se producen tres episodios que determinan el fin del idilio entre García Escudero y «sus» nuevos directores y que a la postre, conduciría al proyecto aperturista del director general al definitivo fracaso.

\section{III.3. Decepción y recrudecimiento intervencionista}

Juguetes rotos, el documental de Summers de 1966 anteriormente citado a raíz de los cortes que sufrió su entrevista a Gorostiza, fue el primero de esos hitos en los que se manifestó de manera irreversible la distancia entre el proyecto aperturista de García Escudero y la realidad. Summers, gran esperanza comercial del director general, se quejó públicamente de que la cinta había sufrido 37 cortes, lo que no debió sentar bien a García Escudero, pues en noviembre de ese mismo año no dudó en remitir a la fiscalía unas declaraciones del director andaluz en las que denunciaba la existencia de irregularidades en la concesión de subvenciones a la industria del cine. Si bien las diligencias no prosperaron, la ruptura inevitable entre el alto cargo y su favorito presagiaba sin duda el final de una etapa.

Una vez más, el contexto político en el que el régimen se adentraba, influyó como no podía ser de otra manera en el fin del sueño aperturista. La involución política en que se sumió el Estado con la promulgación de la Ley Orgánica del Estado, el nombramiento de Carrero Blanco como vicepresidente del gobierno, el retorno a los Consejos de Guerra y la devaluación de la peseta como consecuencia de 
las crisis económica, tuvieron su repercusión en el ministerio de Información y Turismo, que con la excusa de un reajuste presupuestario, se suprimió la Dirección General de Cinematografía, cuyas competencias fueron asumidas por la nueva Dirección General de Cultura y Espectáculos, a cuyo frente se colocó a Carlos Robles Piquer, que desde 1962 ejercía la dirección general de Información del Ministerio.

No obstante lo anterior, si bien es ineludible la responsabilidad del fracaso aperturista por parte de la administración franquista y su nefasta gestión de la industria cinematográfica, sería injusto ignorar otros factores que sin duda coadyuvaron al fracaso del Nuevo Cine Español como vehículo de apertura cultural. Uno de ellos sin duda fue el escaso predicamento que este cine «culto» cosechó en el terreno de la recaudación en taquilla, siendo significativo al respecto el dato recabado de las tablas de recaudación entre los años 1965 y 1970, en el que de los 1.843 films estrenados, el primero de un director del Nuevo Cine Español, El juego de la Oca (1966) de Summers, aparece situado en el puesto $108^{16}$.

La segunda debilidad de la que adoleció esta corriente creadora fue especialmente dolorosa para estos nuevos directores habida cuenta de que afectaba a su razón de ser. En efecto, como ya tuvimos ocasión de ver al inicio de este capítulo, uno de los proyectos de García Escudero fue utilizar el cine como correa de transmisión de la modernidad y excelencia de la cultura española, a través de la producción de películas con calidad suficiente para poder competir y obtener galardones en los más importantes festivales de cine internacionales. Pues bien, La Caza (Oso de Plata en Berlín) y La niña de luto (1964) y El juego de la oca (1966), seleccionadas para Cannes, fue el escaso bagaje a nivel de premios que el NCE alcanzó en los festivales internacionales ${ }^{17}$.

Por último, tampoco se libró este nuevo cine de las envidias y animadversiones dentro del propio gremio. La vieja industria nunca asumió que la calificación -y la subvención, claro está- de Interés Especial fuese siempre concedida a productos "de festivales», lo que generó a García Escudero constantes presiones de los sectores más rancios de la industria, siempre bien conectados con las jerarquías del régimen.

${ }^{16}$ La película más taquillera de la década fue La ciudad no es para mi, (1966, Lazaga).

${ }_{17}$ Aunque se benefició del proteccionismo estatal (Emiliano Piedra y Ángel Escolano), Campanas a medianoche (1965, Welles), que obtuvo el Premio 20 Aniversario y el Gran Premio Técnico del Festival de Cannes de 1966, no puede decirse que fuese Nuevo Cine Español. 
Al hilo de este último comentario, resultaría incompleta la visión de esta década si nos limitáramos a analizar el referido cine «culto» sin hacer mención a la producción que pudiéramos denominar comercial que, al margen de ser la que realmente sostenía la débil industria merced al éxito de público de las mismas, ofreció algunos subgéneros de naturaleza vernácula e imposible implantación en otra cinematografías, de indudable interés.

Las notas dominantes de estos productos de ficción, formatos de aluvión de géneros clásicos eran la escasez de medios, un diseño de producción elemental y el trazo grueso de los diálogos, con constantes lugares comunes, chascarrillos y tópicos de tosca factura. Con estos mimbres, artesanos de la realización como Ozores, Ramón Fernández, Lazaga o Palacios, junto con intérpretes procedentes del teatro popular, con tendencia por el histrionismo, pero no exentos ni mucho menos de talento, dieron carta de naturaleza a la comedia «a la española ${ }^{18}$. Pero sin duda, si hubo en la década de los sesenta en España un soporte económico de la industria ese fue el spaghetti-western, subgénero cinematográfico de extraordinario éxito, realizado a través de coproducciones italo-españolas privilegiadas por las subvenciones indirectas y las exenciones fiscales por ser rodados en «zonas industriales preferentes» como el desierto de Tabernas de Almería, y que a partir de Por un puñado de dólares (1964, Leone), se convirtió en un fenómeno económico y social de inimaginables proporciones gracias fundamentalmente a directores como el mítico Rafael Moreno Marchent ${ }^{19}$, y del que también participaron realizadores que habían vivido mejores épocas, pero que encontraron cobijo económico en estas producciones, como fue el caso del atemporal Iquino, eso sí, bajo el pseudónimo de Nick Nostro (Un dólar de fuego, 1963) o Antonio del Amo (Solo contra tutti, 1965), y de jóvenes que intentaban abrirse paso (Brandy, 1963, Borau).

18 Por donde transcurrieron arquetipos del cazurro o paleto español (La ciudad no es para mi, 1965, Lazaga, Martínez Soria), del reprimido y estereotipado español medio (Operación secretaria, 1966, Ozores, López Vázquez), de la joven española de humilde origen y más llana formación (¡Cómo está el servicio! 1968, Ozores, Gracita Morales), de la niña o niño prodigio (Joselito vagabundo, 1966, Morayta, Joselito; Búsqueme a esa chica, 1964, Palacios, Marisol), así como vehículo de contenidos claramente humillantes para la mujer en una sociedad de arraigado machismo (No deseará a la mujer del prójimo, 1968, Lazaga), de ensalzamiento de la familia en su acepción de virtuosa proliferación (La familia y uno más, 1966, Palacios) o el curioso subgénero de renovación clerical acomodada a los tiempos (Sor ye-ye, 1967, Fernández o El padre Coplillas, 1968, Comas).

19 En 1978 obtuvo un colosal éxito televisivo con la serie «Curro Jiménez», a la que sin duda podemos considerar como una versión española del far-west. 


\section{III.4. Tristana}

Esta frustrante década acaba sin embargo con una grata noticia para el cine español, que sin embargo no pudo ocultar el inicuo y caprichoso sistema censor. Nos referimos claro está a las vicisitudes que hubo de sufrir la producción hispano-italo-francesa de Tristana, la adaptación cinematográfica que Buñuel realizó de la obra galdosiana. Eduardo Ducay, de Época Films, planteó ante la Dirección general el proyecto de la película, sometiendo el guión al examen de la Junta, que lo rechazó en su totalidad. La decisión de Buñuel, ampliamente divulgada, de trasladar el rodaje a Portugal, activó los resortes del ministerio de Información, siendo Fraga en persona el que revocó el bloqueo del argumento autorizando el rodaje de Tristana en España. Nótese que, a pesar del escándalo mayúsculo que supuso en su día $V i$ ridiana, de la mórbida relación entre la Deneuve y Fernando Rey (hijo, por cierto, del general Casado), y del republicanismo confeso del director, sin embargo, Fraga era consciente del enorme prestigio de Buñuel y no dudó un instante en dejar al lado los otrora rígidos criterios censores, para recibir con los brazos abiertos al genio de Calanda a quien, esa hipócrita hospitalidad de las autoridades franquistas le granjeó no pocas críticas por su supuesta integración y adaptación al sistema.

Tristana fue nominada a los Oscars para la categoría de mejor película de habla no inglesa y galardonada además con el Premio del... Sindicato Nacional del Espectáculo!!

\section{SE CIERRA EL CÍRCULO: DE LA OSCURIDAD DE SÁNCHEZ BELLA AL FRUSTRADO NUEVO APERTURISMO DE PÍO CABANILLAS (1970-1975)}

\section{IV.1. Crisis económica e integrismo moral}

El periodo comprendido entre el año 1969 y la larga agonía y muerte del general Franco, constituye el último estadio de este apresurado recorrido por la historia del cine español durante la dictadura. Y en contra de toda lógica, aislado de las tendencias socioculturales vigentes en los países de nuestro entorno, autista frente a las demandas de regeneración política y social provenientes de amplios sectores de la sociedad, el cine español, o mejor dicho, la Administración franquista con competencias en materia cinematográfica, no solo no avanzó en estos años de manera acorde con las corrientes cul- 
turales y artísticas de otros países de nuestro entorno geográfico, que no cultural, sino que, como anunciamos en el epígrafe de este capítulo, se produjo un evidente retroceso en materia cinematográfica sometiendo aún más si cabe a la industria del cine a la asfixiante tutela de la administración, sin que los más de treinta años transcurridos desde la victoria rebelde en la guerra civil hubieran atemperado el pernicioso proteccionismo que la administración se atribuía en defensa de los sagrados principios del Movimiento y de una ciudadanía a la que aun tenía por menor de edad en 1970. Mas al contrario, de la mano del nuevo gobierno de Carrero Blanco de octubre de 1969, con Sánchez Bella como nuevo titular de la cartera de Información y Turismo, del que ya pudimos apreciar su talante en la célebre carta remitida al ministro Castiella cuando era embajador en Roma a raíz del estreno en Venecia de El Verdugo, y su mano derecha en la Dirección general de Cultura y Espectáculos, Enrique Thomas de Carranza, se trató de conectar esta nueva etapa con la intransigente época de Arias Salgado, eludiendo en la medida de lo posible cualquier referencia al pretendido aperturismo representado por Fraga y García Escudero y reafirmándose en la tesis según la cual, los valores artísticos no deben ser los únicos protegidos por los poderes públicos, debiendo hallarse un justo equilibro entre éstos y los principios morales que sostienen la sociedad española.

A este panorama cultural tan deprimente, se adicionó, durante esta última etapa, un segundo factor que vino a sumir en la más profunda crisis económica a la enjuta industria cinematográfica española. Como no podía ser de otra manera, este elemento distorsionador procedía también del plano político.

El escándalo MATESA y sus consecuencias inmediatas arrastraron al Banco de Crédito Industrial, entidad de crédito que se encargaba del abono a los productores del 15\% del taquillaje a que todo film español tenía derecho conforme a la regulación diseñada por García Escudero, por lo que a comienzos de 1970, la Administración franquista adeudaba a los productores españoles unos 230 millones de pesetas, obligando a muchos cineastas a situarse al margen de las estructuras oficiales, en un remedo de producción underground ${ }^{20}$.

A pesar de las normas orientativas de la censura, instrumento normativo promulgado en la etapa de García Escudero y que tenía

${ }^{20}$ Jaula de todos (1974, Paulino Viota), El hombre oculto (Alfonso Ungría, 1971), Zumo (Álvaro del Amo,1972), El desastre de Annual (Ricardo Franco, 1970), Correo de guerra (Augusto Martínez Torres,1972) Carnet de identidad (Llorenç Soler, 1972), ¿Qué hay para cenar? (Antoni Padrós, 1972). 
como finalidad dotar de cierta seguridad jurídica a los realizadores, así como evitar los agravios comparativos con el cine de importación, la iniquidad en esta funesta etapa se consolidó de manera sistemática, cercenándose por ejemplo la violencia necesaria de El bosque del lobo (1970, Olea) al tiempo que se estrenaban sin cortapisas todos los sanguinolentos productos que la Hammer tenía a bien producir en el Reino Unido.

Sería interminable la relación de desmanes que la censura perpetró en este periodo, por lo que nos referiremos a un caso arquetípico de la acción administrativa sobre el cine español en estos años y que ponen de manifiesto hasta que punto se encontraba España, literalmente, en otro mundo.

A las arbitrariedades de la Junta y al caciquismo de los directores de Festivales, hay que añadir la nefasta influencia que sectores inmovilistas del régimen ejercieron sobre la producción cinematográfica, configurándose así un censura paralela ${ }^{21}$, de naturaleza social, que en aras de la protección de la moral de la sociedad, enmendaban la plana a los órganos administrativos encargados de tal menester. Con el documental de Martín Patino Canciones para después de una guerra (1976) ocurrió exactamente eso. Tras ser visionada cinco veces en el Pleno de la Junta de Censura y la mutilación de 27 planos, acabó obteniendo la calificación de Interés Especial declarándola autorizada para todos los públicos, mediante autorización de 4 de junio de 1971. Lo que no sabía el director salmantino era que Félix Martalay, militar y crítico de cine del diario El Alcázar y de la revista Film Ideal, y que ya había visionado el documental en su condición de miembro de la Junta de Censura, denostó de manera inmisericorde la película en un artículo - «Canciones para después de una guerra o llanto para después de una paz»— firmado bajo seudónimo - Carlos F. de Avellanos- en el referido diario madrileño, replicando así al elogioso articulo de Antonio Crespo publicado en el diario Arriba el 30 de mayo de 1971, lo que desencadenó un agrio intercambio de reproches entre Antonio Izquierdo desde el Arriba y el propio Martalay desde las páginas del Alcázar ${ }^{22}$. A esta controversia no fue ajeno lógicamente el gabinete de Carrero Blanco, quien asistió personalmente a un nuevo revisionado a petición del Ministro del Ejército Castañón

${ }^{21}$ La guerra de Dios (1953, Gil), estuvo suspendida durante varias semanas como consecuencia de la denuncia del Colegio de Médicos, al aparecer en el film un galeno con escasos escrúpulos deontológicos.

22 NIETO, J. «La memoria cinematográfica en la Guerra Civil española» Universidad de Valencia, Valencia, 2008. 
de Mena, culminando este proceso con una nuevo dictamen de una Comisión Especial del Ministerio de Información ${ }^{23}$ en el sentido de prohibir definitivamente el largometraje $\mathrm{e}^{24}$.

De esta manera, las tres décadas de prácticas censoras, incrementadas ahora de la mano del ultraconservador binomio Sánchez BellaThomas de Carranza en un ejercicio de desfase histórico-cultural, habían creado una sociedad fuertemente reprimida en muchos aspectos, especialmente el sexual, merced a las lúbricas obsesiones de los censores durante tantos años, lo que acarreó que, mientras en Bonn, Londres, Paris o Roma, se estrenaban Le Grand beouff (1973,Ferreri), A clocwork orange (1971, Kubrick), Ill Portieri de notte (1974, Cavani) o Ultimo tango a Parigi (1972, Bertolucci), en España, el hito sexual del momento era No desearás el vecino del quinto (1970, Ramón Fernández), lo cual no es reprochable desde luego a la manipulada sociedad española, sino a las enfermizas restricciones eróticas sufridas por las generaciones españolas de la posguerra y que sirvió de burdo sucedáneo autóctono - rayano con la patología sexual- del verdadero cine erótico que se rodaba y estrenaba en todo el mundo.

Este subgénero, desde el punto de vista comercial, vino a sustituir con innegable éxito el otro filón taquillero de la anterior década, el spaghetti-western, encumbrando al film de Ramón Fernández citado, como el más taquillero de la historia del cine español hasta el advenimiento de Torrente, un producto por cierto muy similar en su factura al que ahora nos referimos ${ }^{25}$. La comedia sexy española, de imposible extrapolación a ninguna cinematografía internacional ${ }^{26}$ radicaba su éxito en la presentación de relaciones sexuales patológicas, absurdamente grotescas, con velludos hombres españoles de ingobernable priapismo, persiguiendo bien a frígidas y decorativas mujeres españolas - la decencia de la mujer española era dogma-o a voluptuosas y pánfilas suecas, cuando no presentando auténticas aberraciones sexuales, trufadas de fetichismos anacrónicos.

${ }^{23}$ Esta Comisión ad-hoc estuvo formada por Monseñor Santos Beriguistain, Luis Martos Lalanne (militar), Antonio Torres-Dulce (magistrado), José Ignacio Ecobar Kirkpatrick (político)y Enrique Thomas de Carranza.

${ }^{24}$ GARCIA MARTINEZ, A.N. "El cine de no ficción en Martín Patino» Ediciones Internacionales Universitarias, Madrid, 2008.

${ }^{25}$ Nótese que a día de hoy, las películas más vistas, no las que más recaudaron, son, por este orden: Los Otros (Amebabar), La muerte tenía un precio (Leone), No desearás al vecino del quinto (Fernández) y La ciudad no es para mi (Lazaga).

${ }_{26}$ Con la excepción de la serie de subproductos sicalípticos de los hermanos Martino protagonizados por el incomparable Alvaro Vitali y la no menos mítica y escultural Edwige Fenech. 
Junto al subgénero casposo-sexual, otro de los sustitutos del western ibérico que obtuvo también una notable rentabilidad fue el denominado terror hispánico, que si bien su film inaugural fue La marca del hombre lobo (Eguiluz, 1967), primer largometraje con el legendario Waldemar Daninsky, personaje creado por Paul Naschy, su origen remoto debe ubicarse en la mítica Gritos en la noche (1961) del prolífico y maestro de la serie B, Jesús Franco. Entre los cultivadores de este género fantástico, dejando al margen a los especialistas como José Luis Madrid (El vampiro de la autopista, 1970) Ossorio (El ataque de los muertos sin ojos, 1973); Klimovsky (La orgía nocturna de los vampiros, 1973); Aured (El retorno de Walpurgis, 1973); Zabalza (La furia del hombre lobo, 1972) o Pérez Tabernero (Las alegres vampiras de Vögel, 1975), hubo interesantes aportaciones de cineastas muy dotados que sin embargo las circunstancias les hicieron buscar amparo en este subgénero, como Vicente Aranda (La novia ensangrentada, 1972), Gonzalo Suárez (Morbo, 1972) o Portabella (Cuadecuc Vampir, 1971).

En junio de 1973, Carrero Blanco es nombrado Presidente del gobierno, siendo el políticamente agotado Sánchez Bella sustituido como ministro de Información y Turismo, por Fernando de Liñan y Zofio, paradigma de tecnócrata del Opus, quien había ocupado los cargos de secretario general del Plan de Desarrollo, director general de Asistencia Social y director general de Política Interior, y que durante el breve periodo de su mandato, se ocupó casi exclusivamente de preparar la imagen pública del futuro rey de España, organizándole una intensa agenda de viajes y todo tipo de eventos para darle a conocer a la sociedad.

Tras el atentado terrorista que le costó la vida al presidente Carrero, le sustituye en el cargo Arias Navarro, ministro de Gobernación hasta entonces, dando a conocer su nuevo gabinete el 3 de enero de 1974, nombrando como titular de Información y Turismo al hacedor de la aperturista Ley de Prensa e Imprenta, Pío Cabanillas Gallas, una inequívoca declaración de intenciones para el mundo del cine en lo que sería la ultimísima fase de la dictadura franquista.

\section{IV.2. Renovadas ilusiones, reiteradas frustraciones}

A pesar de la década echada a perder, el último gobierno franquista de Arias Navarro se planteó de nuevo la tarea de airear el panorama político español iniciando una senda innovadora en parecidos términos de lo acontecido en 1962 con la llegada de Fraga a 
Información y Turismo. A pesar de episodios tan dramáticos y execrables como la ejecución de Puig Antich o el escándalo del obispo Añoveros, el «espíritu del 12 de febrero» se reflejó esencialmente en las políticas desarrolladas por Pío Cabanillas ${ }^{27}$ al frente de la cartera de Información y Turismo, y en particular en el ámbito de la prensa escrita, la cual se convirtió en foro de debates ideológicos de notable calado y sin cortapisas previas. Sin embargo, una vez más, el mundo del cine no se vio agraciado por esa corriente aperturista, y al margen de algunas autorizaciones de desnudos o semidesnudos ${ }^{28}$, persistía la relación de naturaleza paternalista entre la Administración y la industria cinematográfica, cuando no de indisimulada intolerancia entre los sectores más involucionistas del régimen y las producciones más audaces. La breve permanencia de Cabanillas al frente de Información y Turismo tuvo mucho que ver precisamente con las presiones que hubo de soportar al defender la viabilidad de determinadas películas en contra de las presiones más cerriles del propio gabinete.

El ejemplo arquetípico de esta situación fue sin duda La prima Angélica (1974, Saura), prudente intento de abordar las relaciones entre los vencedores y los vencidos, que a pesar de obtener el Premio Especial del Jurado en Cannes ese mismo año, fueron objeto sus proyecciones de continuos ataques fascistas, alcanzando mayor gravedad el incendio de la fachada del cine Balmes de Barcelona el 11 de julio, por lo que la película hubo de ser retirada del cartel. A pesar ello, Arias Navarro respaldó la decisión de su ministro de mantener la cinta en el resto de salas.

Pero no fue un caso aislado, factores como la creciente contestación interna al régimen, el propio desgaste evidente del franquismo o la cada vez más acuciante necesidad de expresarse de una generación que no había vivido la guerra civil, fueron determinantes a favor de la eclosión de una corriente de producción fílmica que vino a denominarse «cine de oposición», caracterizada, en primer lugar, por contener corrosivas críticas al régimen y a la sociedad que los sostenía, eso sí, de manera elíptica o metafórica, no en vano, aún estaba vigente la

27 Como director general nombró al historiador Ricardo de la Cierva y como subdirector general de cine al empresario taurino Rogelio Díaz.

${ }^{28}$ El primer desnudo integral del cine español fue protagonizado por una enfermera (M. ${ }^{a}$ José Cantudo) en La Trastienda (1975, Grau). El desnudo se muestra durante 3 segundos en un metraje de 99 minutos pero creó un escándalo que eclipsó otros aspectos de la trama convirtiendo la cinta en uno de los éxitos comerciales de la década, incluso del cine español. Ocupa el n. ${ }^{\circ} 24$ dentro de las 50 películas españolas de mayor número de espectadores en España desde su estreno hasta el 31/diciembre /1987, y el puesto n. ${ }^{\circ} 42$ entre las 50 de mayor recaudación. 
doble censura cinematográfica y, en segundo término, por aunar éxito en la crítica y en un público cada vez menos adoctrinado. De hecho, la rentabilidad de este cine convirtió en productor de éxito a un independiente como Querejeta, que apostó fuerte por el cine de oposición con taquilleras películas como El espíritu de la colmena (Erice), La prima Angélica y Cría cuervos (Saura), Pascual Duarte (Franco) o El desencanto (Chávarri) ${ }^{29}$.

Sin perjuicio de lo anterior, debe no obstante subrayarse la excelencia de tres títulos por encima de los demás: la ya referida La prima Angélica que, con Cría cuervos (1975) consagran a Saura como un cineasta superlativo y, cómo no, la primera Concha de Oro de San Sebastián para un film español, El espíritu de la colmena (1973), considerada por muchos como la obra cumbre de nuestra filmografía, en la que Víctor Erice, a través del angustiosa sensación de desamparo emocional que rodea a todos los personajes, describe de manera metafórica y con un lenguaje visual nunca visto hasta entonces la España de los años cuarenta, un país machacado por la guerra y hambriento, sin más referentes que la intolerancia de los vencedores. Lo hermético del guión quedó de manifiesto cuando Fernán Gómez, que interpreta al apicultor, confiesa que mientras rodaba, era incapaz de comprender nada del argumento. Algo parecido debió pasarle a la censura que no tocó ni una coma del guión.

A la vez que se alcanzaba con El espíritu de la colmena las más altas cotas de poesía cinematográfica, consagrando la factura autoral y los contenidos elípticos, un antiguo guionista, reconvertido en productor, José Luis Dibildos, tuvo la audacia y el instinto de producir un puñado de películas que vinieron a definirse como «la Tercera Vía», pues si bien se alejaba voluntariamente del cine formalmente arriesgado y elíptico representado por Saura, Erice u Olea, también mantenía un distancia insalvable con el cine comercial más chabacano, produciendo películas de temas de actualidad, rodadas por profesionales clara-

${ }^{29}$ Dentro de esta corriente hubo, como es lógico, una amalgama de sensibilidades muy dispares entre sí, pudiendo encontrarse en su seno desde el liberalismo coyuntural de Jaime de Armiñan que ya había facturado una inclasificable cinta con la extraordinaria Mi querida señorita en 1971 (El amor del capitán Brando, 1974) hasta la radicalidad más acentuada de Olea (Pim, pam, pum... fuego, 1975), pasando por el revisionismo de Camus en Los días del pasado (1976) o la reivindicada emancipación de la mujer en Emilia: parada y fonda (1976, Fons) adaptación del relato de Carmen Martín Gaite "Un alto en el camino: Las ataduras» que contenía el inolvidable tema de Aute, Así sea. En este heterodoxo grupo puede incluso señalarse a un recuperado Bardem para el cine más comprometido con su film El poder del deseo (1975) así como al siempre irregular Borau, con su metafórica denuncia de la violencia en Furtivos (1975). 
mente progresistas - Garci, Drove, Bodegas, Ana Belén, Tina Sainz, Goytisolo o Paco Ibáñez-, con diálogos frescos y ágiles muchos en clave de comedia, en los que se introducían cuestiones más o menos tabúes, como el aborto, la vida sexual de la pareja, etc., con una voluntad clara de reflejar al nuevo español. En este particular, resulta innegable que Pepe Sacristán fue el paradigma del perfecto español de la transición. Puede decirse que esta Tercera Vía se inauguró con la cinta de Roberto Bodegas Españolas en París (1969), siguiendo esta senda títulos del mismo director como Vida conyugal sana (1973), Los nuevos españoles (1974) o Tocata y fuga de Lolita y Mi mujer es muy decente, dentro de lo que cabe (1974), ambas de Antonio Drove.

Junto a Dibildos y su productora Ágata Films, otro productor que cultivó también con éxito esta Tercera Vía fue sin duda el propietario de Kalender Films, Antonio Cuevas, que junto con Manuel Summers como director y María Isabel Álvarez y Beatriz Galbó como principales interpretes, explotó las frustraciones sexuales de su generación con películas como Adiós cigüeña, adiós (1970), El niño es nuestro (1972) o Ya soy mujer (1974).

El desgaste biológico e institucional del régimen generó en el seno del gabinete franquista y del resto de las estructuras administrativas un cada vez menos disimulado clima de enfrentamiento entre los sectores más reacios a cualquier signo aperturista y los que, sin ser precisamente unos adalides del liberalismo, si entendían la indefectibilidad de un cambio habida cuenta del contexto socio-político imperante.

La destitución de Cabanillas y su sustitución por el general de división consejero togado del Cuerpo Jurídico militar del Aire, León Herrera Esteban - la inolvidable voz que leyó el parte de fallecimiento del general Franco- puso bien a las claras las dificultades casi insuperables de cualquier atisbo de democratización de la industria cinematográfica española mientras no se produjese el «hecho biológico inevitable», habida cuenta de la distancia sideral entre una administración anquilosada y una sociedad absolutamente alienada de la autoridades gobernantes.

Adviértase que en diciembre de 1974, 36 años después de terminada la guerra, mientras en Nueva York se estrenaba The Godfather II, en Paris se aplaudía Tamaño natural de Berlanga, o en Roma se proyectaba la ganadora del Gran Premio del Jurado de Cannes Il fiore della mille e un notte de verano de Passolini, nuestra España estrenaba una nueva Junta de Ordenación Cinematográfica, cuyos intérpretes eran cuatro funcionarios del ministerio de Información, cuatro ma- 
gistrados — dos de ellos de los Tribunales de Peligrosidad Social y de Orden Público-, dos sacerdotes dominicos, un economista, un guionista y un crítico de cine, un periodista y un programador de TVE, un policía y un miembro de la delegación de Juventud, que configuraban la Comisión de Lectura de Guiones, a las que se añadían, para formar la Comisión Enjuiciadora de Películas, el siguiente elenco: tres militares, un guardia civil, una madre de familia, un miembro de la sección femenina y dos funcionarios más, uno de ellos proveniente de Educación y Ciencia.

\section{CONCLUSIONES}

Con una Administración fosilizada desde el 1 de abril de 1939, que durante la dictadura franquista se hayan producido y proyectado películas como Ella, él y sus millones, La vida en un hilo, Bienvenido Mister Marshall, Calle Mayor, El verdugo, Viridiana, La caza, Nueve cartas a Berta, Tristana, La prima Angélica o El espíritu de la colmena, sin duda obedece a factores que se sitúan extramuros de la calidad de esos films y que entronca directamente con la intervención divina, habida cuenta de los muchos terminales clericales que visionaron, analizaron y censuraron cada milímetro de celuloide de esos largometrajes. Si no, no puede explicarse razonablemente como una industria absolutamente mediatizada por la acción administrativa en sus más variadas manifestaciones proteccionistas y represoras, pudo dar frutos tan extraordinarios como los referenciados. La audacia de esos cineastas junto con la parquedad de miras de los censores, permitieron que obras maestras del cine no se quedaran para siempre en los estantes oscuros de un almacén o definitivamente destruidas, lo que demuestra que a pesar de la obscena y obstinada voluntad manipuladora de las administraciones públicas en los procesos creativos, cualquiera que sea su manifestación, la mediocridad intelectual de los sujetos encargados de realizar esa mezquina labor les impidió una y otra vez apreciar el verdadero significado de muchas de esas obras, deteniendo su pacata fiscalización en la supresión de aspectos epidérmicos, que en nada afectaron, venturosamente, a la calidad de aquellas creaciones. 